\title{
Influence of chronic undernutrition and leptin on GOAT mRNA levels in rat stomach mucosa
}

\author{
C Ruth González ${ }^{1,2}$, María J Vázquez ${ }^{1,2}$, Miguel López ${ }^{1,2}$ and Carlos Diéguez ${ }^{1,2}$ \\ ${ }^{1}$ Department of Physiology, School of Medicine, University of Santiago de Compostela, 15782, Santiago de Compostela, Spain \\ ${ }^{2}$ CIBER Fisiopatología de la Obesidad y Nutrición (CIBERobn), Spain \\ (Correspondence should be addressed to C Diéguez; Email: carlos.dieguez@usc.es)
}

\begin{abstract}
The most unique feature of ghrelin is the acyl-modification of a hydroxyl group of the Ser3 in the N-terminus. The Ser3 is commonly modified by $n$-octanoic acid in vertebrates being needed for its biological effects, at least in terms of feeding. Therefore, a critical question regarding the role of ghrelin was to characterize the mechanism involved in its acylation. The acyltransferase that catalyzes ghrelin octanoylation has been recently identified and named ghrelin $O$-acyltransferase (GOAT). The aim of this study was to clarify the physiological implications of GOAT in the regulation of energy balance, by assessing the effect of undernutrition, as well as fasting in adult male rats. We have determined GOAT mRNA expression levels by real time-PCR in the stomach mucosa. Our results show that chronic food restriction led to an increase in GOAT mRNA, particularly following long-term chronic malnutrition (21 days). Furthermore, following $48 \mathrm{~h}$ complete fasting, a situation with high-circulating ghrelin levels, we found similar mRNA expression of GOAT in fed and fasted rats; exogenous leptin administration markedly increase GOAT mRNA levels in the stomach mucosa of fasted rats. These findings suggest that increased GOAT mRNA levels may have a role in mediating the physiological responses to chronic undernutrition and could represent an adaptive response to prevent long-lasting alterations in energy balance and body weight homeostasis. Furthermore, our data also offer mechanistic insights into the reason why during fasting acylated ghrelin levels are not increased at a time when a marked increase in an orexigenic signal as important as acylated ghrelin will be expected.
\end{abstract}

Journal of Molecular Endocrinology (2008) 41, 415-421

\section{Introduction}

Ghrelin released from ghrelin-producing cells in the stomach circulates through the body and exhibits multiple biological actions in different tissues. Data gleaned over the last few years have shown that ghrelin is the most potent endogenous orexigenic peptide in both rodents and humans (Kojima et al. 1999, Tschop et al. 2000, Wren et al. 2001, van der Lely et al. 2004, López et al. 2008a). Ghrelin's important physiological role of body weight and metabolic homeostasis derives from several facts, such as those indicating that a) ghrelin might be an important signal to prepare for meal initiation in humans and rodents (Cummings et al. 2001, Drazen et al. 2006); b) deletion of ghrelin (and/or its receptor) prevents highfat diet-induced obesity, increased basal insulin level, enhanced glucose-stimulated insulin secretion, and improved peripheral insulin sensitivity; and c) ghrelin modulates key hypothalamic neuropeptide systems, such as agouti-related protein/neuropeptide $\mathrm{Y}$ and hypothalamic metabolic pathways, such as fatty acid synthesis and oxidation, regulating feeding (Broglio et al. 2004, Dezaki et al. 2004, 2006, Gauna et al. 2004, 2006, Iwakura et al. 2005, Granata et al. 2007, López et al. 2008a,b).
These effects suggest that ghrelin has unique actions on the handling of metabolic substrates in general and on key components of glucose homeostasis.

The most unique feature of the ghrelin structure is the acyl-modification of a hydroxyl group of the serine residue at position 3 of the N-terminal of ghrelin. The Ser3 is commonly modified by $n$-octanoic acid in vertebrates being needed for its biological effects, at least in terms of feeding (Gutierrez et al. 2008, Yang et al. 2008). Since the effects of ghrelin on GH secretion and food intake were initially only observed after administration of the acylated form, besides the fact that unacylated ghrelin (UAG) was unable to bind to the type la of ghrelin receptor (GHS-R) led initially to suggestions that UAG was devoid of biological activity (Kojima et al. 1999). However, it is currently clear that in some cases the biological effects of ghrelin are mediated by the acylated form properly, with UAG being inactive, whereas in other effects UAG can mimic ghrelin action or even exert antagonistic effects (Gauna et al. 2004, 2006, Dezaki et al. 2006, Granata et al. 2007). In this sense, it is now believed that the ratio acylated/UAG is particularly important in terms of glucose homeostasis. Thus, it has been found that endogenous ghrelin inhibits the glucose-induced insulin

DOI: 10.1677/JME-08-0102 Online version via http://www.endocrinology-journals.org 
release via the GHS-R1a, as demonstrated by the marked increase of insulin response to glucose after deletion of the ghrelin gene (Dezaki et al. 2006). Moreover, ablation of the ghrelin gene improves glucose tolerance, insulin secretion, and insulin sensitivity in genetically leptindeficient $(o b / o b)$ obese mice (Sun et al. 2006). Administration of exogenous ghrelin suppresses further insulin secretion, and it worsens insulin sensitivity and glucose tolerance after a meal or a glucose load (Broglio et al. 2004). UAG administration neither has effects on glucoseinduced insulin release in a perfused pancreas model, nor induces significant changes in systemic fasting levels of insulin and glucose in vivo (Gauna et al. 2004, 2006, Dezaki et al. 2006, Granata et al. 2007). However, UAG increases insulin release in vitro by insulinoma cell lines exposed to high glucose concentrations (Gauna et al. 2006), and overexpression of (endogenous) UAG in pancreatic islets improves the insulin sensitivity to an i.p. glucose load in mice (Granata et al. 2007). Moreover, when coadministered with ghrelin, UAG completely prevents the ghrelininduced increase in circulating glucose levels and worsens insulin sensitivity (Broglio et al. 2004, Iwakura et al. 2005). These and other effects (Korbonits et al. 2004, van der Lely et al. 2004, Gualillo et al. 2006) illustrate the relevance of the ghrelin/UAG ratio and led to the hypothesis that targeting of the enzyme responsible for ghrelin acylation might be of therapeutic interest for those pathological conditions characterized by insulin resistance and impaired insulin release.

The acyltransferase that catalyzes ghrelin octanoylation has recently been identified and named ghrelin $O$-acyltransferase (GOAT; Hofmann 2000, Gutierrez et al. 2008, Yang et al. 2008), also called membrane-bound O-acyl transferase 4 (MBOAT4). All biochemically characterized members of this superfamily are enzymes transfering organic acids, typically long-chain fatty acids, to hydroxyl groups in membrane-embedded substrates. All of them have several membrane-spanning regions, typically between eight and ten, and share a region of detectable sequence similarity. Structural domains of GOAT are conserved across vertebrates, including lower vertebrates such as zebrafish. Curiously, zebrafish GOAT, which shows $\sim 60 \%$ amino acid homology with the human counterpart, is able to acylate human ghrelin, which suggest a highly conserved evolutive function of this enzyme (Hofmann 2000). The discovery of GOAT brings important questions and raises several therapeutic possibilities. First, drugs inhibiting GOAT might be able to prevent diet-induced obesity and might be an effective therapy for type 2 diabetes, increasing insulin secretion and enhancing peripheral insulin sensitivity. Furthermore, it is believed that research on GOAT will offer new insights into the pathophysiology of energy homeostasis, and might lead to the identification of further therapeutic targets. The aim of this study was to clarify the physiological implications of GOAT in the regulation of energy balance, by assessing its mRNA levels in two different experimental paradigms, namely the effect of acute (fasting) and chronic (21 days) undernutrition in normal male rats. Furthermore, we evaluated the effect of leptin on GOAT expression in fed and fasted rats.

\section{Materials and methods}

\section{Animals}

Male Sprague-Dawley rats (200-250 g) were housed in air-conditioned rooms $\left(22-24^{\circ} \mathrm{C}\right)$ under a 12:12 h light/ darkness cycle and fed standard rat chow and water ad libitum. Animals were killed by decapitation. Tissues were collected and frozen at $-80^{\circ} \mathrm{C}$ until they were used. All the animal procedures were conducted according to the principles approved by the Santiago de Compostela Medical School Animal Care Research Committee.

\section{Screening in rat tissues}

The distribution of GOAT and the other MBOATs predicted in rat (MBOAT 2 and 5) was analyzed in several tissues of adult male rats. Animals were killed by decapitation and all tissues were rapidly snapped frozen on dry ice.

\section{Effect of acute food restriction and leptin}

The effect of fasting on stomach mucosa GOAT and ghrelin mRNA expression was analyzed. Adult males were subjected to food deprivation for $48 \mathrm{~h}$, and stomach mucosa was collected at the end of the fasting period. In addition, the effects of leptin administration upon GOAT and ghrelin mRNA levels were evaluated. One group of animals that received the leptin treatment was fed ad libitum and the other group was fasted during the last $48 \mathrm{~h}$ of treatment. In this setting, rats were injected intraperitoneally with vehicle or recombinant leptin (Sigma) at a dose of $200 \mu \mathrm{g} / \mathrm{rat}$ every 12 h, for 2 days (López et al. 2008a) We used eight animals per group.

\section{Effect of chronic food restriction on stomach mucosa GOAT and ghrelin mRNA expression}

Male rats were randomly assigned on day 1 to one of two dietary groups as previously described (Gualillo et al. 2002): rats fed ad libitum and a restricted group of rats fed with $30 \%$ of the amount of food that ad libitum rats ate the previous day. Male rats at different days of restriction were killed and stomach mucosa samples were collected at $8,12,16$, and 21 days of food restriction. Tissues were frozen at $-80^{\circ} \mathrm{C}$ until processing. We used eight animals per experimental group. 


\section{Plasma leptin levels}

Plasma leptin levels were measured by RIA as previously described (Gualillo et al. 2002, López et al. 2008a) using reagents provided in commercial kits (Rat leptin RIA, Linco Research Inc., St Charles, MO, USA).

\section{RNA isolation and real time quantitative RT-PCR}

Total RNA was isolated from rat tissues using TRIzol (Invitrogen, Life Technologies), according to the manufacturer's recommendations. First-strand cDNA was synthesized from $2 \mu \mathrm{g}$ total RNA by random priming RT. The resulting cDNA was subjected to PCR amplification (Nogueiras et al. 2004a, López et al. 2006, Caminos et al. 2007, Vázquez et al. 2008), using sense and antisense primers specific for the rat GOAT, MBOAT 2 and 5 mRNAs (Table 1). The mRNA levels of GOAT and ghrelin in stomach mucosa were studied by using real time-PCR (TaqMan; Applied Biosystems; Foster City, CA, USA) by using specific primers and probes (Table 1) as described previously. All reactions were carried out using the following cycling parameters: $50{ }^{\circ} \mathrm{C}$ for $2 \mathrm{~min}, 95^{\circ} \mathrm{C}$ for $10 \mathrm{~min}$ followed by 40 cycles of $95^{\circ} \mathrm{C}$ for $15 \mathrm{~s}, 60^{\circ} \mathrm{C}$ for $1 \mathrm{~min}$. For the analysis, the input value of GOAT and ghrelin were standardized to the $18 \mathrm{~S}$ value for the sample group and were expressed compared with the average value for the control group. We used eight rats per experimental group.

To verify the identity of amplified cDNAs, PCR products were electrophoresed on a $1.5 \%$ agarose gel; they yielded DNA fragments of the expected length for all specific genes mRNAs. Primers spanned an intron, providing a control for potential amplification of genomic DNA. PCR products were sequenced to ensure the correct amplified cDNAs (DNA and Protein Sequencing Service, University of Valencia, Spain). Hypoxanthine phosphoribosyltransferase 1 (Hprt1) for rat was used as a control housekeeping gene (Nogueiras et al. 2004a, López et al. 2006, Caminos et al. 2007, Vázquez et al. 2008).

\section{Statistical analysis}

Data were expressed as mean \pm s.E.M. Statistic significance was determined by Student's $t$-test (when two groups were compared) or ANOVA and post hoc Bonferroni test (when more than two groups were compared). $P<0 \cdot 05$ was considered significant.

\section{Results}

\section{GOAT mRNA expression in different tissues}

Expression of the mRNA encoding GOAT, MBOAT2 and MBOAT5 in different tissues was evaluated by RT-PCR using specific primers (Fig. 1A). These analyses demonstrate a specific pattern of expression of the message of the GOAT gene in several tissues in comparison to the other two members of the family, MBOAT2 and MBOAT5. Our data are in general agreement with other reports showing a similar pattern of GOAT mRNA expression in both rodent and human tissues (Gutierrez et al. 2008, Yang et al. 2008). Whether some discrepancies such as the fact that

Table 1 Primers and probes for classic PCR and real time-PCR analysis

\section{Sequence}

Primer/probe
GOAT Fw
GOAT Rv
GOAT Pb
GOAT Fw (Classic PCR)
MBOAT 2 Fw
MBOAT 2 Rv
MBOAT 5 Fw
MBOAT 5 Rv
Ghrelin Fw
Ghrelin Rv
Ghrelin Pb
18S Fw
18S Rv
18S Pb
HPRT1Fw
HPRT1Rv
TAMRA
5'-GGCCGGAGCTTTTCCTCTCT-3' 5'-AAAGGCAGTACGTTACAGGGAAG-3' FAM 5'-TGCCGGCTGTGCTGTTCTTACAACA-3'TAMRA 5'-TGAAAGCCGACTATCTGATCCA-3' 5'-TGGCATTTCCTACTGCATCATG-3' 5'-CCCTCGATGAAAGCAATGTAGTCT-3' 5'-TGAAGGGACAGCTGACTGACGTA-3' 5'-ATTTGCCCCAGATCAGCATGT-3' 5'-GAGCCCAGAGCACCAGAAAG-3' 5'-GCTCGTGGCTGCAGTTTAGC-3' FAM 5'-CCAGCAGAGAAAGGAATCCAAGAAGCCA-3'

5'-CGGCTACCACATCCAAGGAA-3 5'-GCTGGAATTACCGCGGCT-3' FAM 5'-GACGGCAAGTCTGGTGCCAGCA-3' TAMRA 5'-CAGTCCCAGCGTCGTGATTA-3' 5'-AGCAAGTCTTTCAGTCCTGTC-3'
Product (bp)

72

204

267

201

70

186

139
Genebank accession number

NM_001107317

NM_001108016.1

NM_001012189.1

AB029433.1

M11188

NM 012583

MBOAT, membrane bound $O$-acyl transferase. 
A

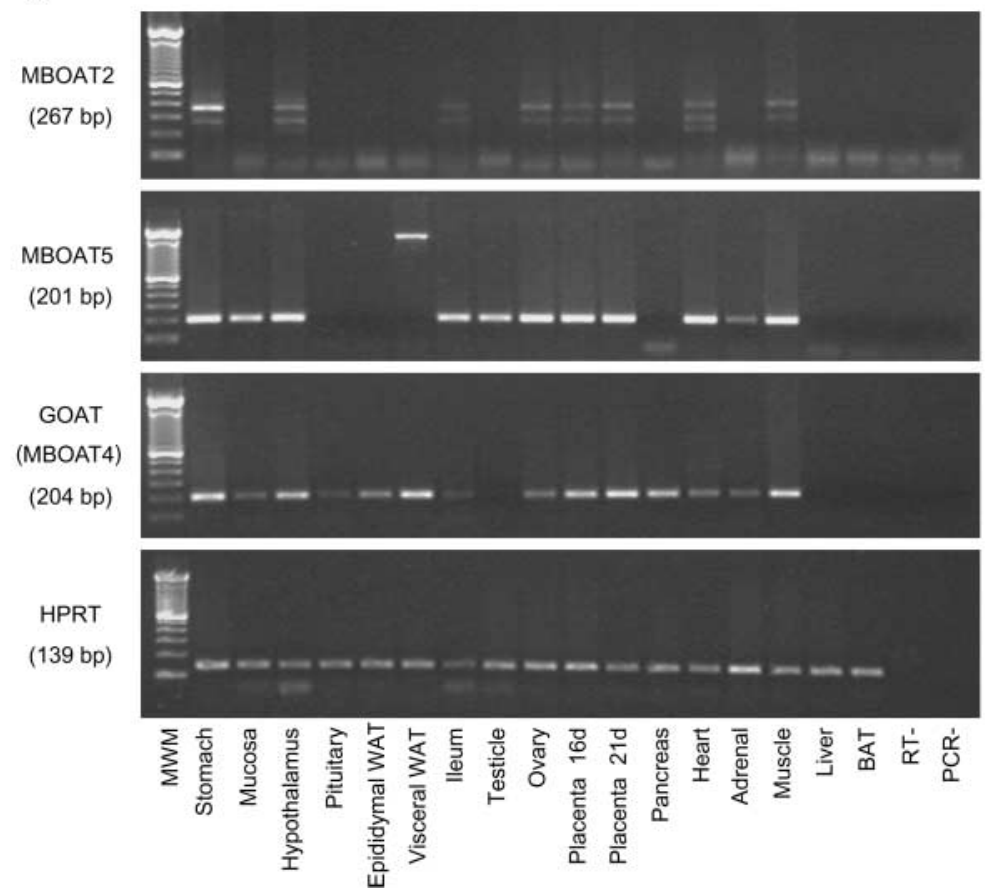

B

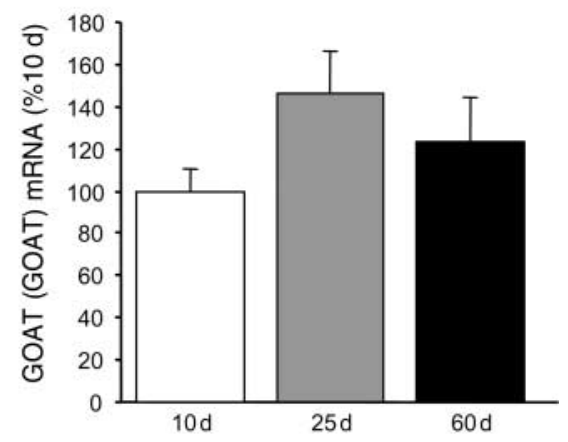

Figure 1 (A) Representative RT-PCR assay of the mRNA expression levels of GOAT (GOAT: membrane bound O-acyltransferase 4), MBOAT2 and 5 in the described tissues. Negative (water) controls are shown. A 100 bp molecular weight marker (MWM) was used. Stomach, total stomach; mucosa, stomach mucosa; WAT, white adipose tissue; BAT, brown adipose tissue. (B) GOAT mRNA (mean+ S.E.M.) expression in the stomach mucosa of male rats at different ages (10, 25, and 60 days old).

GOAT mRNA was detected in testis and liver (Yang et al. 2008) in contrast to our study are related to the use of different animal species remains to be established.

\section{GOAT mRNA levels in rat stomach}

Since the stomach is the most relevant source of acylated ghrelin, we assessed in greater detail GOAT mRNA levels in this tissue. Also since the ghrelinexpressing cells are located in the mucosa, we assessed GOAT mRNA levels in samples extracted from this source. Furthermore, taking into consideration that ghrelin mRNA levels can be influenced by the age of the animals (Gualillo et al. 2001, Cortelazzi et al. 2003), we first assessed GOAT mRNA levels in samples from male rats of different ages. We found that GOAT mRNA levels were relatively stable at all the ages studied (Fig. 1B).

\section{Influence of chronic food deprivation on GOAT mRNA expression in the stomach mucosa of rat}

It is well known that chronic food deprivation leads to marked changes in stomach-derived preproghrelin mRNA levels and circulating acylated- and nonacylated-ghrelin levels. Following a protocol of partial food deprivation the rats started to lose weight as expected (Fig. 2A). A parallel decrease in leptin levels was also observed (Fig. 2B). Despite the changes in body weight, GOAT mRNA levels remained fairly stable until the animals lost a considerable amount of body weight (day 21) where there was a marked and concomitant increase in both GOAT (Fig. 2G) and ghrelin (Fig. 2D) mRNA levels.

\section{Influence of fasting and leptin on GOAT mRNA expression in the stomach mucosa of rat}

In the light of the previous findings of decreased leptin levels and increased GOAT mRNA, we decided to assess the influence of complete fasting, which lead to a rapid decrease in body weight (Fig. 3A) and leptin levels (Fed (mean \pm s.e.m.): $3 \cdot 38 \pm 0.38 \mathrm{ng} / \mathrm{ml}$ versus Fast $48 \mathrm{~h}$ $($ mean \pm s.e.M. $): 0 \cdot 7 \pm 0 \cdot 11 \mathrm{ng} / \mathrm{ml} ; P<0 \cdot 001)$ with and without exogenous leptin replacement, on GOAT mRNA expression in the stomach mucosa of rats. As shown in Fig. 3B, stomach mucosa GOAT mRNA levels were unchanged in $48 \mathrm{~h}$-fasted rats, compared with control ad libitum group. Administration of exogenous leptin failed to modify GOAT mRNA levels in fed rats but markedly increased its expression in fasted rats (Fig. 3B). As expected preproghrelin mRNA levels were increased in fasted rats in comparison with ad libitum fed animals (Fig. 3C). Also preproghrelin levels were 
A

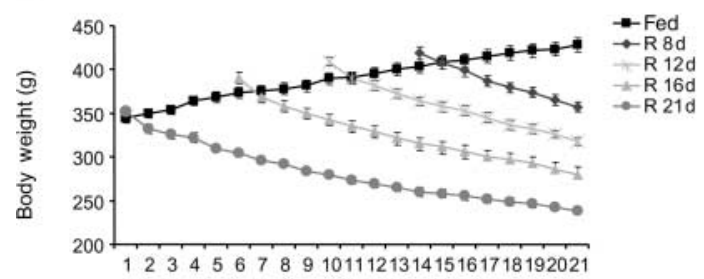

B

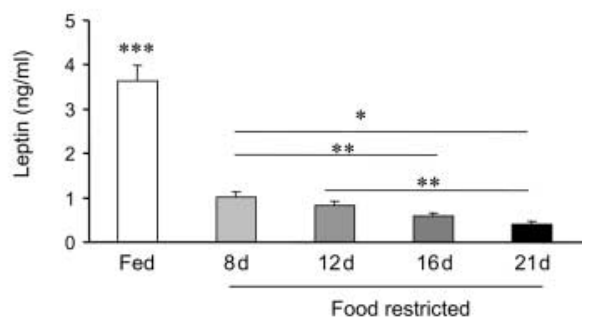

D

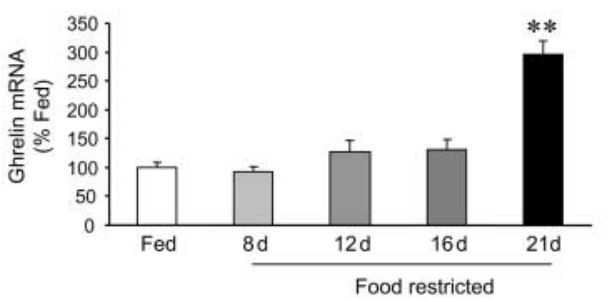

Figure 2 (A) Body weight, (B) plasma leptin levels, (C) GOAT, and (D) ghrelin mRNA expression in the stomach mucosa of fed and food restricted rats at the described times $(8,12,16$, and 21 days). Data are expressed as mean \pm S.E.M. ${ }^{\star} P<0.05$, ${ }^{\star \star} P<0.01$, and ${ }^{\star \star *} P<0.001$ between the labeled groups. In the case of $\mathrm{B},{ }^{* \star \star} P<0.001$ fed versus all the food restricted groups $(8,12$, and 16 days). In the case of $\mathrm{C}$ and $\mathrm{D}$, ${ }^{\star *} P<0.01$ restricted 21 days versus the rest of the described groups $(8,12$, and 16 days).

increased in fed rats after leptin treatment, but no further increase was observed in fasted rats treated with leptin (Fig. 3C). These data confirm that fasting leads to increased availability of preproghrelin mRNA that is further increased by leptin in fed animals while during fasting very low-leptin levels prevent increased GOAT mRNA expression.

\section{Discussion}

The discovery of GOAT appears as a breakthrough in the understanding of ghrelin processing (Hofmann 2000, Gutierrez et al. 2008, Yang et al. 2008). Furthermore, its role of ghrelin acylation will help to understand the regulation of food intake and the pathophysiology of different clinical entities associated with changes in body weight and composition (van der Lely et al. 2004, López et al. 2007). It is well established that total circulating ghrelin levels are markedly influenced by body weight. Thus, the highest circulating levels are usually found in patients with the lower BMI, i.e. patients with anorexia nervosa, and on the contrary obese people exhibit lower ghrelin levels than normal controls (Gualillo et al. 2006). Noteworthy, the hyperghrelinemia in anorectic patients is caused at least partly by increased secretion of acylated ghrelin (Nakai et al. 2003) implying that chronic food restriction leads to a shift in the ratio of acylated/non-acylated ghrelin. On a theoretical basis, the higher proportion of acylated ghrelin could be due to increased expression of the putative enzyme involved in ghrelin acylation or decreased activity of the enzymes, namely hepatic esterases, involved in ghrelin deacylation (Gualillo et al. 2006). To shed some light on this issue we assessed the influence of chronic undernutrition on GOAT mRNA levels in rat stomach mucosa. Our data show that GOAT mRNA levels are relatively stable during periods of decreased food intake. However, once the animals reach a marked weight loss, GOAT mRNA levels are markedly increased. These findings suggest that increased GOAT levels may be the mechanism underlying increased acylated ghrelin levels in chronic undernutrition (Nakai et al. 2003) and may represent an adaptive response to prevent long-lasting alterations in energy balance and body weight homeostasis.

In contrast to chronic undernutrition, data gleaned recently have shown that after a few days of complete fasting, the proportion of acylated ghrelin falls (Liu et al. 2008). Thus, under these conditions, the balance between ghrelin and des-acyl ghrelin may be changed by the regulation of ghrelin acylation. Toshinai et al. (2001) reported that in the stomach of rats fasted for $48 \mathrm{~h}$, the ratio of des-octanoylated ghrelin to $n$-octanoylated ghrelin markedly increased after fasting. Based on that, it was postulated that complete fasting regulates ghrelin activity by a mechanism that inhibits the addition of the acyl group as ghrelin is synthesized. Since this event is dependent on GOAT an obvious possibility was that fasting prevents GOAT expression. Our data show that this may not well be the case since GOAT mRNA levels were not decreased in $48 \mathrm{~h}$-fasted rats in contrast to 

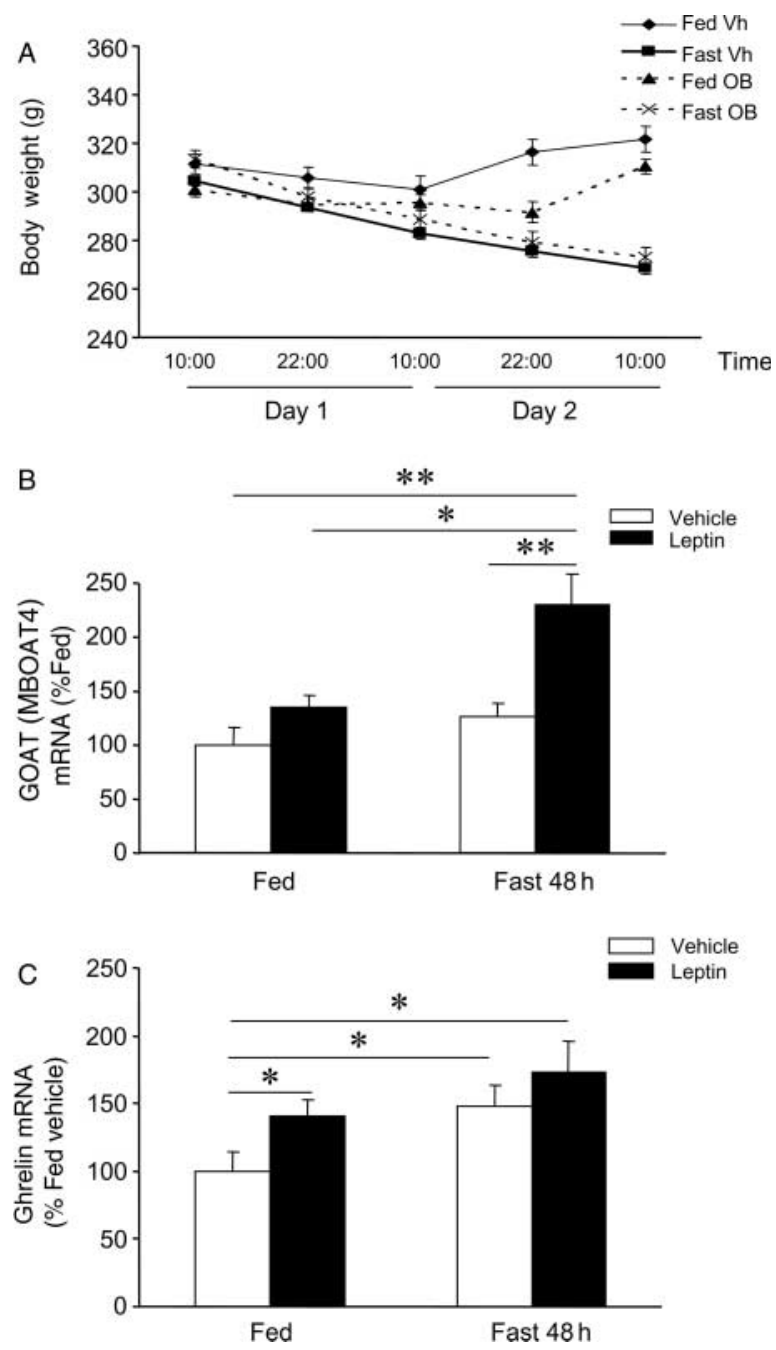

Figure 3 (A) Body weight, (B) GOAT, and (C) ghrelin mRNA expression in the stomach mucosa of fed and fasted rats for $48 \mathrm{~h}$ treated with vehicle or leptin (OB). Data are expressed as mean \pm S.E.M. ${ }^{*} P<0.05$ and ${ }^{* \star} P<0.01$ between the labeled groups.

preproghrelin, which were elevated as expected. Despite the fact that GOAT mRNA levels were not influenced by fasting, and the associated low-leptin levels, we decided to assess the influence of exogenous leptin in GOAT mRNA levels, since it is well established that leptin plays an opposite functional role of ghrelin in food intake and that leptin regulates key components of the ghrelin system such as the ghrelin receptor GHS-R1a (Nogueiras et al. 2004b, López et al. 2007). We found that exogenously administered leptin to fasted rats markedly increased GOAT mRNA levels. These data indicate that during fasting low-leptin levels prevent an increase in GOAT mRNA levels and therefore GOAT can be added to the list of leptin-regulated genes (López et al. 2007) at least under this specific condition. These data also resemble previous results regarding the neuroendocrine effects of leptin which are only uncovered under fasting conditions (Carro et al. 1997, López et al. 2000).

Overall, our data show that chronic undernutrition markedly increased the expression of GOAT mRNA levels in stomach mucosa. Since this is the major source of circulating ghrelin levels (Korbonits et al. 2004, van der Lely et al. 2004, Gualillo et al. 2006), our results offer a mechanistic explanation of the increased acylatedghrelin levels observed in patients with severe malnutrition (Nakai et al. 2003). On the other hand, our data showing that leptin administration in $48 \mathrm{~h}$-fasted rats markedly increased GOAT mRNA levels indicate that low-leptin levels in this setting prevents an increase GOAT mRNA levels. This evidence also offers mechanistic insights into the reason why in this particular paradigm acylated ghrelin levels are not increased at a time when a marked increase in an orexigenic signal, as important as acylated ghrelin, will be expected. Further work on how central stomach GOAT is regulated could provide another important step in unraveling the effect of ghrelin on feeding and glucose homeostasis control, which will improve our understanding of obesity and its treatment.

\section{Declaration of interest}

We declare that there is no conflict of interest that could be perceived as prejudicing the impartiality of the research reported.

\section{Funding}

This work has been supported by grants from Xunta de Galicia (CD and ML: GRC2006/66), Fondo Investigationes Sanitarias (ML: PI061700), Spanish Ministry of Education and Science (MEC; CD: BFU2005), Mútua Madrileña (CD and ML) and European Union (CD: LSHM-CT-2003-503041, Diabesity http://www.eurodiabesity.org). CIBER de Fisiopatología de la Obesidad y Nutrición is an initiative of ISCIII.

\section{References}

Broglio F, Gottero C, Prodam F, Gauna C, Muccioli G, Papotti M, Abribat T, van der Lely AJ \& Ghigo E 2004 Non-acylated ghrelin counteracts the metabolic but not the neuroendocrine response to acylated ghrelin in humans. Journal of Clinical Endocrinology and Metabolism 89 3062-3065.

Caminos JE, Bravo SB, Garcia-Rendueles ME, Ruth GC, Garces MF, Cepeda LA, Lage R, Suarez MA, López M \& Diéguez C 2007 Expression of neuropeptide $\mathrm{W}$ in rat stomach mucosa: regulation by nutritional status, glucocorticoids and thyroid hormones. Regulatory Peptides 146 106-111.

Carro E, Señarís R, Considine RV, Casanueva FF \& Diéguez C 1997 Regulation of in vivo growth hormone secretion by leptin. Endocrinology 138 2203-2206. 
Cortelazzi D, Cappiello V, Morpurgo PS, Ronzoni S, Nobile De Santis MS, Cetin I, Beck-Peccoz P \& Spada A 2003 Circulating levels of ghrelin in human fetuses. European Journal of Endocrinology 149 111-116.

Cummings DE, Purnell JQ, Frayo RS, Schmidova K, Wisse BE \& Weigle DS 2001 A preprandial rise in plasma ghrelin levels suggests a role in meal initiation in humans. Diabetes 50 1714-1719.

Dezaki K, Hosoda H, Kakei M, Hashiguchi S, Watanabe M, Kangawa K \& Yada T 2004 Endogenous ghrelin in pancreatic islets restricts insulin release by attenuating $\mathrm{Ca}^{2+}$ signaling in beta-cells: implication in the glycemic control in rodents. Diabetes $\mathbf{5 3}$ 3142-3151.

Dezaki K, Sone H, Koizumi M, Nakata M, Kakei M, Nagai H, Hosoda H, Kangawa K \& Yada T 2006 Blockade of pancreatic islet-derived ghrelin enhances insulin secretion to prevent high-fat diet-induced glucose intolerance. Diabetes 55 3486-3493.

Drazen DL, Vahl TP, D'Alessio DA, Seeley RJ \& Woods SC 2006 Effects of a fixed meal pattern on ghrelin secretion: evidence for a learned response independent of nutrient status. Endocrinology 147 23-30.

Gauna C, Meyler FM, Janssen JA, Delhanty PJ, Abribat T, van Koetsveld P, Hofland LJ, Broglio F, Ghigo E \& van der Lely AJ 2004 Administration of acylated ghrelin reduces insulin sensitivity, whereas the combination of acylated plus unacylated ghrelin strongly improves insulin sensitivity. Journal of Clinical Endocrinology and Metabolism 89 5035-5042.

Gauna C, Delhanty PJ, van Aken MO, Janssen JA, Themmen AP, Hofland LJ, Culler M, Broglio F, Ghigo E \& van der Lely AJ 2006 Unacylated ghrelin is active on the INS-1E rat insulinoma cell line independently of the growth hormone secretagogue receptor type la and the corticotropin releasing factor 2 receptor. Molecular and Cellular Endocrinology 251 103-111.

Granata R, Settanni F, Biancone L, Trovato L, Nano R, Bertuzzi F, Destefanis S, Annunziata M, Martinetti M, Catapano F et al. 2007 Acylated and unacylated ghrelin promote proliferation and inhibit apoptosis of pancreatic beta-cells and human islets: involvement of $3^{\prime}, 5^{\prime}$-cyclic adenosine monophosphate/protein kinase A, extracellular signal-regulated kinase $1 / 2$, and phosphatidyl inositol 3-Kinase/Akt signaling. Endocrinology 148 512-529.

Gualillo O, Caminos JE, Kojima M, Kangawa K, Arvat E, Ghigo E, Casanueva FF \& Diéguez C 2001 Gender and gonadal influences on ghrelin mRNA levels in rat stomach. European Journal of Endocrinology 144 687-690.

Gualillo O, Caminos JE, Nogueiras R, Seoane LM, Arvat E, Ghigo E, Casanueva FF \& Diéguez C 2002 Effect of food restriction on ghrelin in normal-cycling female rats and in pregnancy. Obesity Research $\mathbf{1 0}$ 682-687.

Gualillo O, Lago F, Casanueva FF \& Diéguez C 2006 One ancestor, several peptides post-translational modifications of preproghrelin generate several peptides with antithetical effects. Molecular and Cellular Endocrinology 256 1-8.

Gutierrez JA, Solenberg PJ, Perkins DR, Willency JA, Knierman MD, Jin Z, Witcher DR, Luo S, Onyia JE \& Hale JE 2008 Ghrelin octanoylation mediated by an orphan lipid transferase. PNAS 105 $6320-6325$.

Hofmann K 2000 A superfamily of membrane-bound $O$-acyltransferases with implications for wnt signaling. Trends in Biochemical Sciences 25 111-112.

Iwakura H, Hosoda K, Son C, Fujikura J, Tomita T, Noguchi M, Ariyasu H, Takaya K, Masuzaki H, Ogawa Y et al. 2005 Analysis of rat insulin II promoter-ghrelin transgenic mice and rat glucagon promoter-ghrelin transgenic mice. Journal of Biological Chemistry 280 15247-15256.

Kojima M, Hosoda H, Date Y, Nakazato M, Matsuo H \& Kangawa K 1999 Ghrelin is a growth-hormone-releasing acylated peptide from stomach. Nature 402 656-660.

Korbonits M, Goldstone AP, Gueorguiev M \& Grossman AB 2004 Ghrelin - a hormone with multiple functions. Frontiers in Neuroendocrinology 25 27-68. van der Lely AJ, Tschop M, Heiman ML \& Ghigo E 2004 Biological, physiological, pathophysiological, and pharmacological aspects of ghrelin. Endocrine Reviews 25 426-457.

Liu J, Prudom CE, Nass R, Pezzoli SS, Oliveri MC, Johnson ML, Veldhuis P, Gordon DA, Howard AD, Witcher DR et al. 2008 Novel ghrelin assays provide evidence for independent regulation of ghrelin acylation and secretion in healthy young men. Journal of Clinical Endocrinology and Metabolism 93 1980-1987.

López M, Seoane L, García MC, Lago F, Casanueva FF, Señarís R \& Diéguez C 2000 Leptin regulation of prepro-orexin and orexin receptor mRNA levels in the hypothalamus. Biochemical and Biophysical Research Communications 269 41-45.

López M, Lelliott CJ, Tovar S, Kimber W, Gallego R, Virtue S, Blount M, Vázquez MJ, Finer N, Powles TJ et al. 2006 Tamoxifen-induced anorexia is associated with fatty acid synthase inhibition in the ventromedial nucleus of the hypothalamus and accumulation of malonyl-CoA. Diabetes 55 1327-1336.

López M, Tovar S, Vázquez MJ, Williams LM \& Diéguez C 2007 Peripheral tissue-brain interactions in the regulation of food intake. Proceedings of the Nutrition Society 66 131-155.

López M, Lage R, Saha AK, Perez-Tilve D, Vázquez MJ, Varela L, Sangiao-Alvarellos S, Tovar S, Raghay K, Rodriguez-Cuenca S et al. $2008 a$ Hypothalamic fatty acid metabolism mediates the orexigenic action of ghrelin. Cell Metabolism 7 389-399.

López M, Saha AK, Diéguez C \& Vidal-Puig A 2008b The AMPKMalonyl-CoA-CPT1 axis in the control of hypothalamic neuronal function. Cell Metabolism 8176.

Nakai Y, Hosoda H, Nin K, Ooya C, Hayashi H, Akamizu T \& Kangawa K 2003 Plasma levels of active form of ghrelin during oral glucose tolerance test in patients with anorexia nervosa. European Journal of Endocrinology 149 R1-R3.

Nogueiras R, Barreiro ML, Caminos JE, Gaytan F, Suominen JS, Navarro VM, Casanueva FF, Aguilar E, Toppari J, Diéguez C et al. $2004 a$ Novel expression of resistin in rat testis: functional role and regulation by nutritional status and hormonal factors. Journal of Cell Science 117 3247-3257.

Nogueiras R, Tovar S, Mitchell SE, Rayner DV, Archer ZA, Diéguez C \& Williams LM $2004 b$ Regulation of growth hormone secretagogue receptor gene expression in the arcuate nuclei of the rat by leptin and ghrelin. Diabetes 53 2552-2558.

Sun Y, Asnicar M, Saha PK, Chan L \& Smith RG 2006 Ablation of ghrelin improves the diabetic but not obese phenotype of ob/ob mice. Cell Metabolism 3 379-386.

Toshinai K, Mondal MS, Nakazato M, Date Y, Murakami N, Kojima M, Kangawa K \& Matsukura S 2001 Upregulation of Ghrelin expression in the stomach upon fasting, insulin-induced hypoglycemia, and leptin administration. Biochemical and Biophysical Research Communications 281 1220-1225.

Tschop M, Smiley DL \& Heiman ML 2000 Ghrelin induces adiposity in rodents. Nature 407 908-913.

Vázquez MJ, González CR, Varela L, Lage R, Tovar S, SangiaoAlvarellos S, Williams LM, Vidal-Puig A, Nogueiras R, López M et al. 2008 Central resistin regulates hypothalamic and peripheral lipid metabolism in a nutritional dependent fashion. Endocrinology 149 4534-4543.

Wren AM, Seal LJ, Cohen MA, Brynes AE, Frost GS, Murphy KG, Dhillo WS, Ghatei MA \& Bloom SR 2001 Ghrelin enhances appetite and increases food intake in humans. Journal of Clinical Endocrinology and Metabolism 865992.

Yang J, Brown MS, Liang G, Grishin NV \& Goldstein JL 2008 Identification of the acyltransferase that octanoylates ghrelin, an appetite-stimulating peptide hormone. Cell 132 387-396.

Received in final form 22 September 2008 Accepted 3 October 2008 Made available online as an Accepted Preprint 3 October 2008 